\title{
Megavoltage pituitary irradiation lowers but seldom leads to safe GH levels in acromegaly: a long-term follow-up study
}

\author{
N C Thalassinos, S Tsagarakis, G Ioannides, I Tzavara and C Papavasiliou ${ }^{1}$ \\ Department of Endocrinology, Diabetes and Metabolism, Evangelismos Hospital, 10676 Athens, Greece and ${ }^{1}$ Department of Radiology, \\ University of Athens, Greece \\ (Correspondence should be addressed to N C Thalassinos, Department of Endocrinology, Evangelismos Hospital, 10676 Athens, Greece)
}

\begin{abstract}
Radiotherapy (RT) has long been used in the treatment of acromegaly, but confusion regarding the definition of biochemical cure has hampered interpretation of previous reports on the outcome of this treatment. In the present study we present additional data using the currently accepted criteria of biochemical cure in a large group of patients followed up by our department. Forty-six acromegalic patients were treated with external beam megavoltage RT and followed up for a mean of 7.6 years (range 2-22 years). Only four patients had had previous surgical treatment by either transsphenoidal or transfrontal routes. Following RT, mean basal GH levels decreased from $30.9 \mathrm{ng} / \mathrm{ml}(5-96 \mathrm{ng} / \mathrm{ml})$ to $11.5 \mathrm{ng} / \mathrm{ml}(1-36 \mathrm{ng} / \mathrm{ml})$ at 10 years of follow up with a further fall to $6.1 \mathrm{ng} / \mathrm{ml}(1-29 \mathrm{ng} / \mathrm{ml}) \mathrm{in}$ those patients followed up for more than 10 years. As a result, although mean GH levels of less than $5 \mathrm{ng} / \mathrm{ml}$ were achieved in $9 / 28(30.1 \%)$ at 5 years, $6 / 19(31.6 \%)$ at 10 years, and in $6 / 11(54.5 \%)$ of those patients followed up for more than 10 years post-RT, only $0 / 28(0 \%), 7 / 28(25 \%), 4 / 19(21 \%)$ and $1 / 11(1 \%)$ achieved GH levels of $<2.5 \mathrm{ng} / \mathrm{ml}$ at $2,5,10$ and $>10$ years following RT. Thus, in the whole series only $10 / 48(20.8 \%)$ patients showed a decrease of GH level to less than $2.5 \mathrm{ng} / \mathrm{ml}$ at their latest follow up. Hypopituitarism as a result of RT was only infrequently observed in this series; gonadal deficiency developed in $12(26.6 \%)$ patients, thyrotrophin (TSH) deficiency in $3(6.6 \%)$ and adrenocorticotrophin deficiency in $2(4.4 \%)$. In conclusion, megavoltage RT is an effective treatment for the control of $\mathrm{GH}$ hypersecretion in acromegaly, with a continuing lowering effect for several years following RT, but seldom leads to safe GH levels.
\end{abstract}

European Journal of Endocrinology 138 160-163

\section{Introduction}

Growth hormone (GH)-secreting adenomas have long been recognised as a cause of increased mortality and considerable morbidity in affected patients $(1,2)$. The current consensus is that the optimal treatment for these adenomas must efficiently and rapidly reduce $\mathrm{GH}$ levels and prevent tumour expansion. Over the last few years transsphenoidal surgery has emerged as the initial treatment of choice for such patients, with cure rates depending on the size and location of the tumour (3-5). However, although cure rates for small tumours are encouragingly high, most patients with larger diffuse adenomas are left with residual GH hypersecretion postsurgery (6-8). Long-term medical treatment with octreotide or dopamine agonists may result in an additional fall of GH levels, but is not curative and thus necessitates life-long administration. Radiotherapy (RT) has long been used in the treatment of acromegaly (9-11), but its long-term effectiveness has been assessed in only a limited number of reports $(10,12-16)$. Moreover, confusion regarding the definition of biochemical cure of acromegaly has hampered interpretation of previous reports on the outcome of treatment (17). In the past, GH levels less than $5 \mathrm{ng} / \mathrm{ml}$ were considered as indicating 'cure' of the patient. However, it has recently been stated that GH levels between 2.5 and $5 \mathrm{ng} / \mathrm{ml}$ are not associated with improvement of the mortality risk in acromegalic patients (18). Thus, a favourable long-term outcome for acromegaly has been suggested to include $\mathrm{GH}$ levels of less than $2.5 \mathrm{ng} / \mathrm{ml}(19,20)$, i.e. much lower than those used in most previous series of irradiated acromegalic patients. In this study, in order to contribute to defining optimum strategies in the treatment of acromegaly, we present additional data on the long-term effects of this therapeutic modality on a large number of patients followed up by our department during the last two decades. The incidence of hypopituitarism and the complications of RT are also presented.

\section{Patients and methods}

Forty-six acromegalic patients (18 males and 28 females, aged 18-72 years, mean 44.5) followed up 
for 2-22 years (mean 7.6) after external pituitary irradiation were included in the present study. Twentyone of these patients have been regularly followed up for at least 10 years. Seven patients had inadequate baseline assessment, but were included in this report since subsequent assessments have confirmed the diagnosis of acromegaly and regular long-term follow up was achieved. All patients had the typical clinical features of acromegaly and the diagnosis was confirmed by the failure of suppression of $\mathrm{GH}$ levels to less than $1 \mathrm{ng} / \mathrm{ml}$ during a $100 \mathrm{~g}$ oral glucose tolerance test. Only four patients had previous surgical treatment by either transsphenoidal or transfrontal routes. When on medical treatment, patients were assessed off medical treatment for at least 2 weeks. GH levels were measured under standard conditions and the mean $\mathrm{GH}$ value from at least two basal samples is reported. Serum GH levels were measured by standard RIA and IRMA (Pharmacia, Uppsala, Sweden). Insulin-like growth factor-1 (IGF-I) levels were measured using a direct assay (Nichols Institute Diagnostics, San Juan Capistrano, CA, USA). Thyroid, adrenal and gonadal functions were regularly assessed by evaluating basal thyroxine $\left(\mathrm{T}_{4}\right)$, free thyroxine index or free $\mathrm{T}_{4}$, cortisol, luteinising hormone, follicle-stimulating hormone, testosterone or oestradiol. Dynamic function was tested at regular intervals by measuring cortisol responsiveness to insulin-induced hypoglycaemia, and gonadotrophin and TSH responses to gonadotrophin-releasing hormone and thyrotrophin-releasing hormone.

\section{Pituitary irradiation}

Pituitary irradiation was carried out using $4 \mathrm{MeV}$ linear accelerators to deliver a lesion dose of 4500-5000 cGy in 25 fractions over 35 days. A three-field technique (two lateral, one frontal) was used to localise radiation to the pituitary and thereby minimise the dose to the optic pathways, brainstem, and temporal lobes.

\section{Results}

Mean basal serum GH levels gradually decreased from $30.9 \mathrm{ng} / \mathrm{ml}$ (range: 5-96; median $25.5 \mathrm{ng} / \mathrm{ml}$ ) to $19.6 \mathrm{ng} / \mathrm{ml}$ (range $4-80$; median $12.5 \mathrm{ng} / \mathrm{ml}$ ) at 2 years; $11.8 \mathrm{ng} / \mathrm{ml}$ (range $1-57$; median $9 \mathrm{ng} / \mathrm{ml}$ ) at 5 years; $11.5 \mathrm{ng} / \mathrm{ml}$ (range: $1-36$; median $10.5 \mathrm{ng} / \mathrm{ml}$ ) at 10 years of follow-up; and a further fall to $6.9 \mathrm{ng} / \mathrm{ml}$ (range: $1-29$; median $4.5 \mathrm{ng} / \mathrm{ml}$ ) in those patients followed up for $>10$ years (Fig. 1). A steep fall of $\mathrm{GH}$ levels was observed during the first 2 years post-RT, with a lesser decrease of $\mathrm{GH}$ levels during the subsequent years of follow-up. However, further lowering of serum $\mathrm{GH}$ levels was also noted even after 10 years following RT. As a result of RT, a significant proportion of patients achieved mean $\mathrm{GH}$ levels of less than $5 \mathrm{ng} / \mathrm{ml}$, reaching $54.5 \%$ (6/11 patients) of those followed up for more than 10 years. However, in the whole series only 10/48 achieved $\mathrm{GH}$ levels of $<2.5 \mathrm{ng} / \mathrm{ml}$ at their latest follow up (Table 1). When pretreatment GH levels were taken into account, a lower final mean $\mathrm{GH}$ level was observed

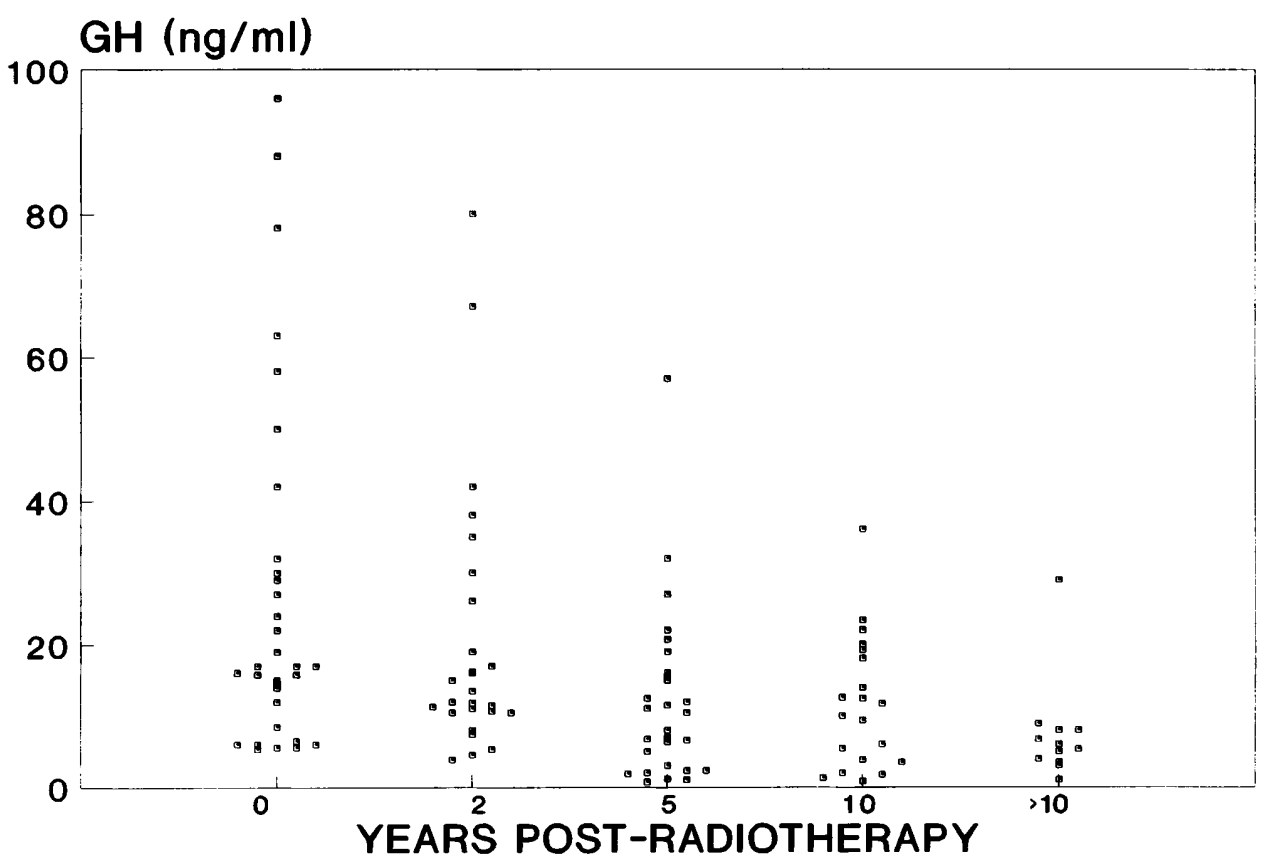

Figure 1 Mean serum GH levels following megavoltage irradiation in 48 patients with acromegaly; a progressive fall of $\mathrm{GH}$ levels is observed but most patients demonstrate $\mathrm{GH}>2.5 \mathrm{ng} / \mathrm{ml}$ even after longterm follow-up. 
Table 1 Number of patients with serum $\mathrm{GH}$ below 5 and $2.5 \mathrm{ng} / \mathrm{ml}$ at intervals after radiotherapy.

\begin{tabular}{|c|c|c|}
\hline & \multicolumn{2}{|c|}{ No. (\%) of patients with GH levels } \\
\hline & $<5 \mathrm{ng} / \mathrm{ml}$ & $<2.5 \mathrm{ng} / \mathrm{ml}$ \\
\hline Before radiotherapy & $0 / 39(0)$ & $0 / 39(0)$ \\
\hline At 2 years & $3 / 28(10.7)$ & $0 / 28(0)$ \\
\hline At 5 years & 9/28(32.1) & $7 / 28(25.0)$ \\
\hline At 10 years & $6 / 19(31.4)$ & $4 / 19(21.0)$ \\
\hline At $>10$ years & $6 / 11(54.5)$ & $1 / 11(0.9)$ \\
\hline
\end{tabular}

in those patients with lower pretreatment GH levels. Thus, in the 18 patients with pretreatment levels of $<25 \mathrm{ng} / \mathrm{ml}$, a GH level of less than $5 \mathrm{ng} / \mathrm{ml}$ was achieved in $12(66 \%)$ at their latest follow-up; significantly higher than $4(19 \%)$ of those 21 with pretreatment $\mathrm{GH}$ levels of $>25 \mathrm{ng} / \mathrm{ml}(P<0.05$, chi-square test $)$. There was no difference in the follow-up period between these groups.

IGF-I levels at latest follow-up were available in 14/21 patients of those followed for at least 10 years. Post-RT IGF-I levels at latest assessment ranged from 0.6 to $5.2 \mathrm{U} / \mathrm{ml}$. Normalisation of IGF-I was achieved in only $4 / 14$ patients.

\section{Side-effects}

Two patients had panhypopituitarism on presentation and remained so on follow-up. One patient had secondary hypogonadism on his initial assessment and remained so on follow-up. Post-RT, 2 patients developed blunted cortisol responses on standard insulin testing ( 5 and 10 years post-RT), 3 became thyroid hormone deficient ( 5,10 and 15 years post-RT), and 12 developed gonadal failure ( 5 patients at 2 years, 4 patients at 5 years and 3 patients at $>10$ years post-RT). Thus, in the whole series, a total of $4.4 \%, 6.6 \%$, and $26.6 \%$ developed corticotroph, thyrotroph and gonadotrophin failure respectively. It is of note, however, that 5/10 patients followed up for more than 10 years developed insufficient secretion of at least one of the anterior pituitary hormones. There was no evidence of any damage to the optic pathways in any patient. No patient showed evidence of tumour expansion or the development of a second malignancy in the irradiation field.

\section{Discussion}

The present study confirms that megavoltage irradiation is an effective treatment for patients with acromegaly, resulting in significant decrease of $\mathrm{GH}$ hypersecretion in a substantial number of patients. As previously reported, following RT a biphasic pattern was observed, with an initial rapid fall of $\mathrm{GH}$ levels during the first 2 years and a further reduction of GH levels in a substantial proportion of patients from 5 years onwards.
Furthermore, in good agreement with the series presented by Ciccarelli et al. (12), we also noted that a progressive fall in $\mathrm{GH}$ levels occurs even 10 years following RT, with a proportion of patients achieving $\mathrm{GH}$ levels $<5 \mathrm{ng} / \mathrm{ml}$ for the first time 10 years after RT. In the present series, in addition to more strict criteria, achievement of mean GH levels of less than $5 \mathrm{ng} / \mathrm{ml}$ was also assessed, in order to allow comparisons to be made with other recently reported series in the literature (13, 15). On the basis of this criterion, our reported remission rate is comparable to those reported series with long-term follow-up, with mean GH levels falling to $<5 \mathrm{ng} / \mathrm{ml}$ in $52-79 \%$ of patients at 10 years of followup (10-16). However, it should be noted that application of more strict criteria to define a favourable outcome significantly lowers the cure rates achieved in irradiated patients, even after long-term follow-up (11). Thus, as shown in the present study, safe GH levels of less than $2.5 \mathrm{ng} / \mathrm{ml}$ are infrequently achieved following external irradiation.

It is of note that, in the present as well as in the most recently published series, there is a striking decrease in the frequency of complications such as brain and optic tract damage and the development of brain tumours, as compared with earlier series (21). This implies that the regimens currently in use for delivering irradiation to the pituitary gland (in terms of fractionation and total dose), have no major adverse effects on brain structures. However, although this is true for the most serious and life-threatening complications, pituitary insufficiency as a result of RT is still reported with increased frequency, with its highest incidence in those patients with the longest follow-up $(12,15,22)$. In the present study, deficiencies in anterior pituitary hormone secretion were only infrequently observed at 5 years following RT. However, $30 \%$ and $50 \%$ of those patients followed up for 10 years, or more than 10 years, respectively, developed deficient secretion of at least one of the anterior pituitary hormones. This may imply that pituitary function loss may eventually appear with increased incidence 10 years onwards following RT, thus necessitating careful life-long follow-up of the patients. Interestingly, Littley et al. (15) have recently suggested that the use of lower $\mathrm{MeV}$ irradiation doses than those most commonly currently used may lead to a significant reduction in the incidence of post-irradiation hypopituitarism. Although such a regimen is of particular importance for younger patients requiring continuing fertility, it will result in unacceptably high incidence of residual $\mathrm{GH}$ hypersecretion using strict criteria.

In conclusion, our findings show that megavoltage irradiation is an effective treatment for the control of tumour expansion and of $\mathrm{GH}$ hypersecretion in acromegaly, with a gradual lowering effect continuing for several years following RT and with best results obtained in patients with lower pre-RT GH levels. Although cure rates according to the strictest criteria 
are rarely seen, RT still remains the sole widely available therapeutic ablative modality for those patients with persistent GH hypersecretion following transsphenoidal surgery. Lower GH levels may not improve final prognosis if they remain over $2.5 \mathrm{ng} / \mathrm{ml}$, but are associated with greater symptomatic relief in those patients unwilling to accept indefinite medical treatment. Our current practice is to irradiate most of our patients with significant GH hypersecretion following transsphenoidal surgery, but in view of the delayed and partial effectiveness of RT, long-term medical therapy with either somatostatin analogues or dopamine agonists is offered in the majority of patients with residual unsafe $\mathrm{GH}$ levels.

\section{References}

1 Wright AD, Hill DM, Lowy C \& Fraser TR. Mortality in acromegaly. Quarterly Journal of Medicine 197039 1-6.

2 Nabarro JDN. Acromegaly. Clinical Endocrinology 198726 481512.

3 Landolt AM, Illig R \& Zapf J. Surgical treatment of acromegaly. In Sandostatin in the Treatment of Acromegaly, pp 23-35. Ed SWJ Lamberts. Berlin: Springer Verlag, 1988.

4 Baskin DS, Boggan JE \& Wilson CB. Transsphenoidal microsurgical removal of growth hormone-secreting pituitary adenomas. Journal of Neurosurgery $1982 \mathbf{5 6} 634-641$.

5 Losa M, Oeckler B, Schopohl J. Muller OA, Alba-Lopez J \& von Werder K. Evaluation of selective transsphenoidal adenomectomy by endocrinological testing and somatomedin- $\mathrm{C}$ measurement in acromegaly. Journal of Neurosurgery 198970 561-567.

6 Quabbe HJ. Treatment of acromegaly by trans-sphenoidal operation, 90-yttrium implantation and bromocriptine: results in 230 patients. Clinical Endocrinology 198216 107-119.

7 Giovanelli MA, Gaini SM, Tomei G, Ducati A, Sganzerla E, Arosio M \& Ambrosi B. Transsphenoidal microsurgical treatment of acromegaly. In Trends in Diagnosis and Treatment of Pituitary Adenomas, pp 215-224. Eds SWJ Lamberts, FJH Tilders, EA Van der Veen \& J Assies. Amsterdam: Free University Press, 1984.

8 Roelfsema F, Van Dulken H \& Frolich M. Long-term results of transsphenoidal pituitary microsurgery in 60 acromegalic patients. Clinical Endocrinology 198523 555-565.

9 Pistenma DA, Goffinet DR, Bagshaw MA, Hanbery JW \& Eltringham JR. Treatment of acromegaly with megavoltage radiation therapy. International Journal of Radiation Oncology, Biology, Physics 19761 885-893.

10 Eastman RC, Gorden P \& Roth J. Conventional supervoltage irradiation is an effective treatment for acromegaly. Journal of Clinical Endocrinology and Metabolism 1979 48 931-940.

11 Feek CM, McLelland J, Seth J, Toft AD, Irvine WJ, Padfield PL \& Edwards CRW. How effective is external pituitary irradiation for growth hormone secreting pituitary tumours? Clinical Endocrinology 198420 401-408.

12 Ciccarelli E, Corsello SM, Plowman PN, Besser GM \& Wass JAH. Prolonged lowering of growth hormone after radiotherapy in acromegalic patients followed for over 15 years. Advances in Biosciences 198869 269-272.

13 Spiers CJ, Reed PI, Morrison R, Aber V \& Joplin GF. The effectiveness of external beam radiotherapy is not affected by previous pituitary ablative treatments. Acta Endocrinologica 1990 122 559-565.

14 MacLeod AF, Clarke DG, Pambakian H, Lowy C, Sonksen PH \& Collins CD. Treatment of acromegaly by external irradiation. Clinical Endocrinology 198930 303-314.

15 Littley MD, Shalet SM, Swindell R, Beardwell CG \& Sutton ML. Low-dose pituitary irradiation for acromegaly. Clinical Endocrinology 199032 261-270.

16 Eastman RC, Gorden P, Glatsein E \& Roth J. Radiation therapy of acromegaly. Endocrinology and Metabolism Clinics of North America $199221693-712$.

17 Melmed S, Ho K, Klibanski A, Reichlin S \& Thorner M. Recent advances in pathogenesis, diagnosis, and management of acromegaly. Journal of Clinical Endocrinology and Metabolism $1995803395-3402$.

18 Bates AS, Van't Hoff W, Jones JM \& Clayton RN. An audit of outcome of treatment in acromegaly. Quarterly Journal of Medicine $199386293-299$.

19 Sheaves R, Jenkins P, Blakburn P, Huneidi AH, Afshar F, Medbak S, Grossman AB, Besser GM \& Wass JAH. Outcome of transsphenoidal surgery for acromegaly using strict criteria for surgical cure. Clinical Endocrinology 199645 407-413.

20 Frohman LA. Acromegaly: What constitutes optimal therapy? Journal of Clinical Endocrinology and Metabolism 199681 443-445.

21 Jones A. Radiation oncogenesis in relation to the treatment of pituitary tumours. Clinical Endocrinology 199135 379-397.

22 Tsagarakis S, Grossman A, Plowman PN, Jones AE, Touzel R, Rees LH, Wass JAH \& Besser GM. Megavoltage pituitary irradiation in the management of prolactinomas: long-term follow-up. Clinical Endocrinology 199134 399-406.

Received 25 February 1997

Accepted 1 July 1997 